\title{
Seeking Social Equity in National Parks: Experiments with Evaluation in Canada and South Africa
}

\author{
Joleen A. Timkoa,", and Terre Satterfield ${ }^{b}$ \\ ${ }^{a}$ Faculty of Forestry, University of British Columbia, \\ \#2900-2424 Main Mall, Vancouver, BC, Canada, V6T-1Z4
}

${ }^{\mathrm{b}}$ Institute for Resources, Environment and Su stainability, University of British Columbia, 421-2202 Main Mall, Vancouver, BC, Canada, V6T-1Z4

\#Corresponding author. Email: joleen.timko@ gmail.com

\begin{abstract}
Many national parks (NPs) and protected areas (PAs) worldwide are operating under difficult social and political conditions, including poor and often unjust relations with local communities. Multiple initiatives have emerged as a result, including co-management regimes and an increased emphasis on the involvement of indigenous people in management and conservation strategies more broadly. Yet, controversy over what constitutes an appropriate role for local people persists, and little research has been conducted as yet to systematically evaluate the extent to which NPs are socially (and not just ecologically) effective. This paper discusses a first attempt to examine the efficacy with which NPs address social equity, including property and human rights, and the relationship of indigenous people and NP managers. The results from an evaluation of equity in a purposive sample of six NPs in Canada and South Africa are presented. All but one of the case study NPs is found to be achieving or moving towards equity. In particular, NPs with more comprehensive co-management and support from neighbouring indigenous groups demonstrate higher equity scores across a variety of indicators, whereas NPs with lower levels of co-management do less well. NPs with settled land claims have not necessarily been more equitable overall, and a few NPs have been co-managed in name only.
\end{abstract}

Keywords: indigenous people, PAs, co-management, public participation, governance, social equity, evaluation

\section{INTRODUCTION}

NATIONAL PARKS (NPS) AND OTHER protected areas (PAs) remain central to enhancing biodiversity conservation across landscapes. Yet many NPs were constituted through the dispossession of local people, and/or persist under unnecessarily poor relations with local communities. For conservation to be successful and enduring, in NPs and PAs, it must address equity concerns. Where equity itself can be defined as "fairness in the distribution of benefits' (Berkes 2004: 627), multiple scholars have identified three factors of fundamental importance to indigenous groups: land tenure or ownership (Balint 2006), access to livelihoods and resources (Burdge 1994; Zerner 2003), and participation in governance (Berkes 1994; A grawal 2003; Zerner 2003). Tense relations between local people and NP officials have arisen due to the forced displacement of many communities from PAs (Brockington \& Igoe 2006; Rangarajan \& Shahabuddin 2006), a sustained disregard for restitution and the absence of prior or ongoing informed consent (Brosius 2004; Blaustein 2007). Understandably, indigenous people around the world are seeking compensation for lost rights, which includes in many post-colonial states the pursuit of land claims in and around NPs (Colchester 2004).

Concurrently, a commitment to involving indigenous people in establishing, governing and managing PAs on a fair and equitable basis has been urged, most notably by The Durban Accord, which was developed during the fifth World Parks Congress (Colchester 2004). This relatively new emphasis on indigenous involvement in NP agencies and sponsoring conservation organisations is manifest in a spate of co-management arrangements. Un-

Copyright: () Timko and Satterfield 2008. This is an open access article distributed under the terms of the Creative Commons Attribution License, which permits unrestricted use and distribution of the article, provided the original work is cited. 
derstood to mean the substantial sharing of PA management, co-management generally includes shared responsibilities and authority between local- and statelevel systems and recognised indigenous stakeholders or groups (Berkes 1994; Brechin et al. 2001). Significant controversy over the appropriate role for indigenous people in NP management and conservation strategies nonetheless remains. Some argue that local human needs are co-opting the ecological integrity of NPs (Terborgh 2004), while others see human rights as inalienable from the development and management of NPs (Harper 2002), argue for new alliances between the conservation community, and indigenous and local communities (Brosius 2004), and call for increased attention to equity concerns of indigenous people including participation, dispossession, assessment of property rights and access restrictions on natural resources (Blaustein 2007).

It is now commonly expected that NPs will better account for the needs of indigenous people. This is in reaction to the fact that the past establishment and management of many NPs often followed a 'fortress conservation' model, i.e., a top-down protectionist, quasicolonial and in some cases a militarised approach to NP management (Bruner et al. 2001; Wilshusen et al. 2002; Buscher \& Whande 2007). NPs of this kind were envisaged as places where rural livelihoods did not belong (Brockington et al. 2006), where nature needed to be preserved as 'wilderness' (Naumann 1998; Colchester 2004), and human habitation was excluded often through the forced removal of local populations (Magome \& Murombedzi 2003; Cernea \& Schmidt-Soltau 2006). The result was often displacement of local inhabitants and/or their impoverishment and psychological harm (Brockington 2002; Brockington \& Igoe 2006; Rangarajan \& Shahabuddin 2006). In addition to these costs, many communities on the periphery of NPs have also suffered from lost access to resources and increased threats from wild animals (Balint 2006).

The purpose of this study is to use the above cited critiques of NPs, whose aim is improved justice in NP management regimes, to develop and test a 'criteria and indicator' examination of social equity in six Canadian and South African NPs. We employ those criteria that have emerged from the literature as central to NP management with regard to the concerns of indigenous people. They are: resolution of land tenure (including unresolved historical loss of rights and those transgressed in the genesis of new NPs); the maintenance of livelihood opportunities (or the resolution of conflicts stemming from loss or changes in local livelihoods); and decisionmaking authority in NP governance. Few studies to date have addressed the role and function of social equity in PA management in a cross-case, similarly comprehensive, and multidimensional manner. Some have, however, used interviews to examine the social mandates of management boards in Australia and South Africa (e.g., Reid et al. 2004) and to understand the needs and concerns of NP-proximate communities in Honduras (Pfeffer et al. 2001). Others still have sought larger samples, randomly sampling ( $n=234$ households) inhabitants of an area buffer zone in Nepal to examine the benefits of local participation in reserve management (Baral \& Heinen 2007); or studied the impacts of a wildlife reserve on resident villagers (Ghate 2003).

We begin below with case study information on the social, ecological and political features of the selected six NPs and NP reserves in Canada and South Africa. This is followed by a detailed description of the methods used to evaluate the extent to which equity mandates were being fulfilled in the respective NPs. Our results are then discussed in reference to the study's key findings on equity as well as some thoughts on their implications for NP management. We conclude by indicating that more can be done to mitigate the social and economic impacts of the NPs including improved access to NP resources and livelihood opportunities for local and indigenous people.

\section{METHODS}

\section{Logic of Case Study National Park Selection}

The considerable qualitative literature on the social dimensions and impacts of NPs comprise several superb case studies, which suggest largely negative impacts on people but imply variation or range in impacts that have yet to be comparatively measured to any extent. As this is a first effort to compare NPs with regard to equity, we necessarily narrowed our selection of case studies using a purposive sample of NPs (a) governed by national policies working to address problems raised by indigenous peoples living in or on the periphery of NPs; and (b) with varying levels of co-management with neighbouring indigenous groups. ${ }^{1} \mathrm{We}$ included only those NPs encompassing land claimed by groups meeting the ILO (1989) definition of indigenous, though we in no way mean to suggest that the concerns of other non-indigenous communities are illegitimate.

We also restricted this study to Canada and South Africa because both countries maintain extensive and long established NPs that are under claim (in part or in whole) by neighbouring indigenous or First Nation groups. In doing so, we do not intend to diminish the possibility that the very different political and economic histories of these two nation states are causative with regard to the equity outcomes of respective NPs. That said, our central aim is the development of an equity-based evaluation in and of itself and with regard to NPs in post-settler/postcolonial nations wherein key parallels exist. In particular, we refer to the legacy of land dispossession in Canada and South Africa followed by the subsequent pursuit of land claims and compensation for rights lost by indigenous peoples. (Including Australian NPs in this sample 
was preferable due to their significant progress with comanagement regimes, but funding restrictions eliminated this possibility as did the absence in Australian NPs of large predator-prey systems as compared to those prevalent in Canadian and South African NPs.)

In Canada, the nineteenth and twentieth century colonial experience of indigenous people can be characterised as a continuing process of encroachment on and transformation of their traditional territories, restriction of their livelihood capacities including government restrictions on hunting and fishing, and population relocation and sedentarisation (Berg et al. 1993; Usher 2003). NPs have been both embedded in and have exacerbated these hardships. Since the late 1970s, Parks Canada policy has increasingly tried to define a new relationship between indigenous groups and potential NPs. While this effort has been more successful in newer NPs (e.g., Gwaii Haanas) as compared to older NPs with more entrenched practices indicative of their colonial pasts (e.g., Banff or Waterton Lakes NPs), the move towards better NP-people relations is federally pervasive. There are indications that all future NPs will be negotiated via some form of comanagement agreement, reflecting a Parks Canada's policy shift towards these initiatives (Weitzner \& Manseau 2001). This is due in a large part to both the settlement of comprehensive land claims in the north, and to the Berger inquiry which partly recognised the need to establish northern PAs for the purpose of preserving both wildlife habitat and the natural landscapes underpinning the traditional economies of the Inuvialuit and the Dene (Berg et al. 1993; Morrison 1997).

The institution of comprehensive land claims processes in northern Canada and the crucial lobbying efforts on the part of northern indigenous groups, resulted in Parks Canada pursuing a NP reserve' designation for some new NPs. These NPs specifically acknowledge that First Nations, the Inuit or the Metis people (the terms given to indigenous people in Canada), can claim outstanding rights or interest to some NP lands. Pending the settlement of any such rights or interests through treaty or ot her negotiations, the 'NP reserve' status ensures that indigenous rights are not extinguished, i.e., the right to carry out activities integral to cultural and social endurance are protected (Morgan et al. 1997), while allowing the area to be managed with the protection afforded to all NPs under the Canada National Parks Act (Berg et al. 1993; DJC 2000; PC 2003). Yet, in both NP reserves and the older NPs, an ad hoc approach to accommodating the needs of indigenous people has often meant that few rights are accorded to them in practice (Berg et al. 1993).

In South Africa, land dispossession based on apartheid (extending from 1948 to 1994) policies forced 'black' and 'coloured' people onto 'black homelands' or 'coloured reserves', respectively (Reid et al. 2004). ${ }^{3}$ Much of the country's PA network was created under these same apartheid policies (Brockington \& Igoe 2006), which forced relocation of black Africans onto clearly demarcated, contrived and artificial ethnic 'homelands' closely resembling the way wildlife was circumscribed in 'NPs' and 'game reserves' (Carruthers 2006, 2008).

Since majority rule began in 1994, the democratic go vernment in South Africa has made several substantive changes to deal with the legacy of colonialism and to redress the inequities caused by apartheid (Carruthers 2007). For instance, at the national level South Africa National Parks (SANParks) was restructured to reflect the demographics of society with new senior personnel appointed from historically disadvantaged sectors of the society, and a new Social Ecology Unit (now renamed People and Conservation) was created (Grossman \& Holden 2002). Perhaps most especially, the Restitution of Land Rights Act (DLASA 1994) has allowed communities and individuals to file a claim for land from which they had been removed after 1913 .

Through land restitution, the full ownership and title deeds to claimed land have been turned over to several communities, including land within the NPs included in this study. The claimants in these NPs decided to maintain their land under conservation, and entered into a 'contractual NPs' agreement with the government (Grossman \& Holden 2002). Contract NPs are managed by the national conservation authority according to the terms of a joint management agreement, and are emerging as a mechanism for meeting the country's conservation and development objectives (Reid et al. 2004). For instance, lands were turned over to the Makuleke community at the northern end of the Kruger NP, turning that region into a contract park, while also establishing a comprehensive NP forum structure to aid communication between the NP and the approximately 187 villages sit uated near its border. Kgalagadi NP settled a formal land claim with the $\ddagger$ Khomani $\mathrm{San}^{4}$ and the Mier communities in 1999, turning a portion of the NP into a contract park. The $\ddagger$ Khomani San people of Kalahari are part of the San, some of the 'first people' of southern Africa and believed to have been living in the region for more than 20,000 years; where their ancestors lived and migrated as hunter-gatherers (Bosch \& Hirschfeld 2002). The Mier, while not technically 'indigenous' as the term is used in this paper, are an Afrikaans -speaking, marginalised minority who came to live in the Northern Cape in 1865 , and who had lived on and farmed land in Kgalagadi NP and now occupy a former 'coloured' reserve (Bosch 2003). The Mier community has also experienced a history of dispossession, and their settlements have poor water supplies and no electricity, education and job opportunities are limited, literacy is estimated to be 10 percent, and most rely on farming for their income (Social Ecology and SANParks 2000 as cited in Reid et al. 2004: 388). The Mier and the $\$$ Khomani San have been living in close proximity for a very long time and many are now linked through familial lines. 
The Makuleke, the $\$$ Khomani San and the Mier communities are permitted to use the land within their contract parks. For example, the $\$$ Khomani San community members may conduct activities pertaining to 'conservation and sustainable economic, symbolic and cultural use compatible with conservation' (Bosch \& Hirschfeld 2002: 168). This means hunting wildlife and gathering plants in what is considered a sustainable manner (as determined by SANParks), using the land for educational purposes and possibly developing eco-tourism facilities such as accommodation or $4 \times 4$ trails (Hughes 2005). However, as the lands returned by restitution from conservation have remained under conservation management via lease agreements with the claimant communities, such agreements may have been a condition of return in the first place (Reid et al. 2004; Brockington \& Igoe 2006).

NPs in Canada and South Africa differ in the extent of indigenous involvement in NP management, employment and decision-making processes. For example, the $\mathrm{H}$ aida Nation (Canada) has recognised that the natural and cultural elements of their home island of Haida Gwaii are inseparably intertwined. In partial anticipation of their pending land claim with regard to these islands, the Haida initiated the designation of Gwaii Haanas as a Heritage Site in 1985, which enabled them to prevent further logging on Lyell Island (AMB 2002), an important site wit hin the island chain. ${ }^{5}$ In 1988, the Government of Canada protected Gwaii Haanas as a NP reserve, and together with the Council of the Haida Nation, cooperatively manages the NP under an Archipelago Management Board (AMB) (AMB 2002). Likewise, in Canada's Yukon Territory, Kluane NP and Reserve is co-operatively managed based on shared responsibility and requires a sound and effective government-to-government relationship between Parks Canada, and the Champagne-Aishihik and the Kluane First Nations (PC 2004).

Comparatively, a strong commitment to co-management in South Africa's NPs is not as yet evident. SANParks sees commercialisation of the NP's assets and employ ment of 'black' and 'coloured' South Africans as more effective routes to empowerment than comanagement (Reid et al. 2004). While such efforts for increasing empowerment may be sincere, such efforts elsewhere have been accused of being directed at improving public relations rather than devolving any genuine decision-making powers (Gibson \& Marks 1995). Indeed, in both the Kruger and Kgalagadi (the latter in particular), genuine involvement in decision-making activities is limited.

In sum, while these respective nation states have approached restitution differently, there is evidence (with sufficient variability for design as noted below) of active programmatic efforts to recognise the deeply pejorative legacies of NPs, address land claims and develop programmes of co-management and public participation.

\section{Selecting Canadian and South African Case Study Parks}

Purposive sampling, following Babbie and Benaquisto (2002), was used to select case study NPs that also fell within designations set out by the World Conservation Union Category II (IUCN 1994). Theoretical replication was the basis of our sampling logic, wherein specific NPs were selected because they would provide contrasting results but for predictable reasons (such as the level of co-management) (Yin 2003). Each of the case study NPs had varying levels of indigenous involvement and power sharing within their respective governance structures (Berkes 1994). Because of the broader aims of the study and the concomitant need for data sources, the selection of case studies was also restricted to NPs that had data sources from which we could draw, including explicit management plans and ecological monitoring data.

Case study NPs varied in size, regional ecosystem type, co-management strategy, and the range of management and conservation concerns (Table 1). The six NPs included in this study were: Kluane, Gwaii Haanas and Pacific Rim NP Reserves and Waterton Lakes NP in Canada, and the Kruger and Kgalagadi NPs in South Africa. Gwaii Haanas was selected because it is fully co-managed, i.e., the co-management board maintains the authority to make a variety of decisions about the NP. This is contrasted with the Kluane's co-manage ment board where authority over decision-making is restricted and Waterton Lakes where there are no formal co-management arrangements with the NP's neighbouring indigenous groups. Pacific Rim operates in a 'post-treaty' environment with some co-operative initiatives, though no formal NP co-management board exists as yet. Finally, the Kruger and Kgalagadi have both settled land claims and established portions of the NP as 'contract parks' with the relevant indigenous and tribal neighbours. For the sake of brevity, throughout the paper we refer to each NP by its first name (e.g., Kluane for Kluane NP Reserve).

\section{Development of Equity -based Criteria and Indicators}

A comprehensive review of the literature on communities and natural resources (Berkes 2004; Balint 2006), critiques of NPs (Adams et al. 2004; Oltremari \& Jackson 2006), sustainable livelihoods (Chambers \& Conway 1991), social impact assessment (Burdge 1994; Vanclay \& Bronstein 1995; Burdge 2004), and common property theory (McKean 2000; Agrawal 2003) in relation to PAs elucidated the need to examine how effectively problems of equity are addressed in NPs and other PAs. Based on these literatures, three criteria emerged as central to characterising social equity in NPs: the resolution of land tenure and ownership (including the provision of compensation for lost land rights); the maintenance of livelihood opportunities (in order to mitigate further impacts 
Table 1

Information on the six case study national parks

\section{NP: Waterton Lake NP}

Country and location: Canada, southwest corner of Alberta, northern portion of the Waterton-Glacier International Peace Park

Year established:1895

Area (sq km): 525

Indigenous groups: Kainai (Blood) First Nation, Piikani (Peigan) First Nation

Co-management board (if applicable): None

Main management/conservation challenge: Small size of NP relative to large migratory wildlife using the NP, external influences from increasing human populations, climate change

\section{NP: Kluane NP and Reserve}

Country and location: Canada, southwest corner of Yukon Territory

Year established: 1976

Area (sq km): 21,980

Indigenous groups: Champagne and Aishihik First Nation, Kluane First Nation

Co-management board (if applicable): Kluane Park Management Board

Management/conservation challenge: Climate change, predator/prey interactions, forest pests

\section{NP: Gwaii Haanas NP Reserve and Haida Heritage Site}

Country and location: Canada, $130 \mathrm{~km}$ off northwest coast of British Columbia

Year established: 1993

Area (sq km): 1,470

Indigenous groups: Council of the Haida Nation

Co-management board (if applicable): AMB

Management/conservation challenge: Spread of invasive and alien biota, seabird conservation

\section{NP: Pacific Rim NP Reserve}

Country and location: Canada, west side of Vancouver Bland

Year established: 1970

Area (sq km): 499

Indigenous groups: Ditidhat First Nation, Hupacasath First Nation, Huu-ay-aht First Nation, Pacheedaht First Nation, Tla-o-quiaht First Nation, Toquaht First Nation, Tseshaht First Nation, Uchucklesaht First Nation, Ucluelet First Nation

Co-management board (if applicable): Qu'aas West Coast Trail Society for West Coast Trail unit of NP only, full co -management board established once treaties settled

Management/conservation challenge: Narrowness of the Long Beach Unit, anthropogenic impacts on water quality, shoreline protection, large numbers of tourists

\section{NP: Kruger NP}

Country and location: South Africa, Eastern Mpumulanga and Limpopo Provinces

Year established: 1926

Area (sq km): 19,485

Indigenous groups: 37 claims pending, one settled with the Makuleke community

Co-management board (if applicable): Contract park with Makuleke and seven NP forums ${ }^{\mathrm{a}}$

Management/conservation challenge: Alien biota, internationally significant biodiversity, water quantity, fire management, hđerogeneity, large population density on border of NP

\section{NP: Kgalagadi NP}

Country and location: Northern portion of Northern Cape Province bordering Namibia and Botswana, part of the Kgalagadi Transfrontier Park Year established: 1931

Area (sq km): 9,591

Indigenous groups: $¥$ Khomani San and Mier communities

Co-management board (if applicable): Contract park with the Mier and the $\$$ Khomani San communities and one NP forum ${ }^{\mathrm{a}}$

Management/conservation challenge: NamaKaroo vegetation, ungulate migration, predator/prey interactions

${ }^{a}$ NP forums are structures established by SANParks whereby communities are encouraged to participate in the management of their local NP and raise issues affecting their lives and the environment. The scope of concern is extensive and ranges from HIV/AIDS through to employment and problems such as the security of NP fences. Representatives elected by the community help to minimise friction between the NP and its neighbours (SANParks 2007). People involved in the NP forums have the ability to influence decision-making and management in the NPs, but the forums are not themselves decision-making bodies. 
on indigenous peoples' livelihoods, to guarantee indigenous people access to resources and to provide employment); and participation in NP governance (in order to enable indigenous and tribal people to influence decisions that will affect them).

A preliminary list of indicators was derived by consulting the literature mentioned above, and management plans and management direction statements from a broader set of 14 NPs and provincial parks in Canada, Australia and South Africa (see Timko \& Satter field 2008). Site sp e- cific visits to the selected six case study NPs included interviews (see below) withkey stakeholders and review of onsite documents. This allowed the list of indicators ge nerated inductively from the interviews and document data to complement those generated deductively from the literature critically examining the social consequences of NPs (Boyatzis 1998). Thirty-nine indicators of equity were evaluated for each NP (Table 2).

The interviews were crucial as the refinement of indicators was a product of both careful coding and iterative

Table 2

Criteria and indicators (n=39) used in interviews with indigenous co-managers to evaluate how the six national parks addressed equity issues

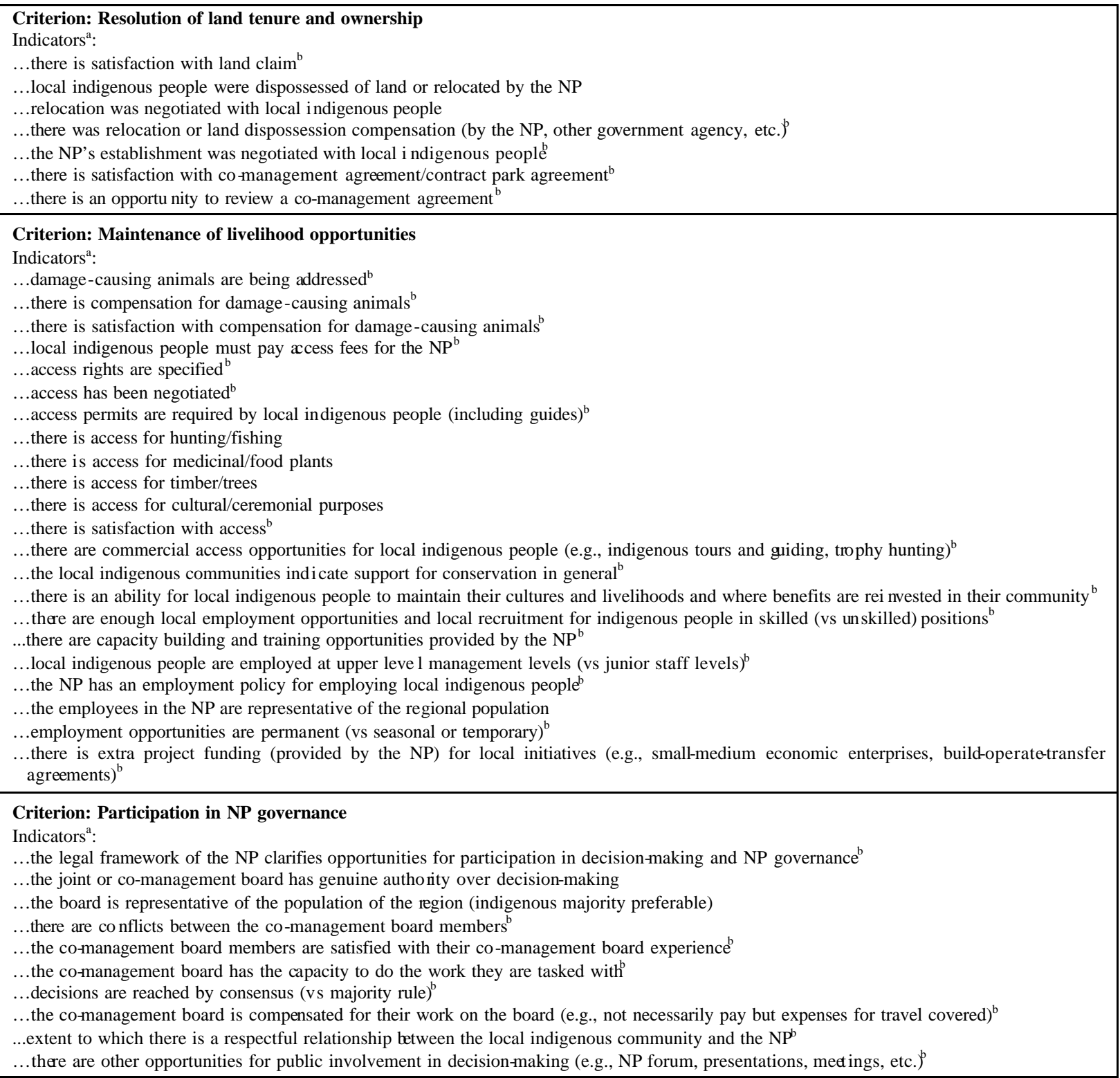

${ }^{a}$ Each of the indicators was measured for 'the extent to which' it achieved the indicator using a 4 point satisfaction scale.

${ }^{\mathrm{b}}$ Denotes indicators that emerged inductively through analysis of interview transcripts. 
reflections on themes extant in the literature on NPs and social equity. This process consisted of coding relevant segments of interview and document data (detailed below) according to the themes reflecting the three crit eria of equity used in this study and included in the topics covered by the interview schedule. The data analysis software QSR N6 (QSR International Pty Ltd 2002) was used to store interview and archival data fr coding and analysis. Once all of the data had been separated according to the main themes, more nuanced codes were assigned to each piece of data (which could have been a respondent's quote or statement, a section of a final land claim agreement or a statement from meeting minutes). These more specific sub-codes pertained to such topics as: permits required for indigenous access into the NP; access to specific resources (plants, timber, bushmeat); level of satisfaction with co-management agreement; level of satisfaction with experience on the co-management board; and conflict amongst members of the comanagement board. Even if a piece of data could have been assigned more than one code, it was assigned only the most appropriate one. We continually revisited, condensed and refined what amounted to 50 codes into the final list of 39 indicators used for analysis.

\section{Interview Design, Sampling and Data Collection}

Interviews were conducted between October 2005 and May 2007 on research trips to each NP. Semi-structured interviews were conducted in English using an openended set of questions. The interviews were designed to elicit qualitative characterisations and ratings for each indicator. In each NP, the first author interviewed as many indigenous representat ives on NP co-management boards and NP forums as possible, along with the NP superintendent or manager and other NP staff involved in comanagement activities and indigenous liaison (Table 3). A total of 30 interviews were conducted across the six NPs. The number of interviews conducted with indigenous people at each NP varied, and ranged from two in- digenous members of NP co-management boards at Kluane, Pacific Rim and Waterton Lakes, to four at the Kruger and Kgalagadi (Table 3). In Pacific Rim and Waterton Lakes where formal co-manage ment boards did not exist, interviews were conducted with First Nations representatives who liaise with the NP on land management issues. The AMB at Gwaii Haanas, comprised two Parks Canada and two Haida Nation representatives, requested to be interviewed as a collective.

The interview guide itself comprised 22 main questions; its central aim was to capture the level of satisfaction of the indigenous co-managers with access to NP resources, livelihood and employment opportunities, and participation in decision-making. Int erviews were conducted in confidence at a place selected by the respondent. These sources were triangulated with other sources wherever possible to help verify qualitative data (Yin 2003). In particular, document analyses complemented data obtained from interviews, and included: contracts and joint management plans, NP management plans, and co-management board and NP forum meeting minutes. Additional clarification and data were collected via email after these visits as necessary.

\section{From Assignation of Rating s to National Park Evaluation}

In order to segue from data coding to evaluating NPs for social equity, we followed a three-fold process: the rating of all data points, the calculation of NP equity and an assessment of the contribution of the three criteria (restitution/land tenure, livelihood opportunities and participation in governance) to each NP's overall equity score. These are detailed below. We also tested if overall NP equity scores were inadvertently driven by the sheer force of population pressures (or lack thereof) across the different NPs, and if the timing of a NP's origin was also an overriding factor (such that the scores for older NPs were simply a function of the nineteenth and twentieth century colonial institutions pervasive at their origin).

Table 3

List of semi-structured interview respondents

\begin{tabular}{|l|l|}
\hline NP & Individuals interviewed (and their positions) \\
\hline Waterton Lakes & NP superintendent and two representatives from the Kinai Nation who liaise with the NP ${ }^{\text {a }}$ \\
\hline Kluane & $\begin{array}{l}\text { NP superintendent, and the chair, manager and two Champagne-Aishihik First Nations members of the Kluane Park } \\
\text { Management Board }\end{array}$ \\
\hline Gwaii Haanas & AMB consisting of two Haida and two Parks Canada representatives (including the acting NP superintendent) \\
\hline Pacific Rim & NP’s indigenous liaison spedalist, president and coordinator of the Quu'as West Coast Trail Society \\
\hline Kruger & $\begin{array}{l}\text { Head of Kruger’s People and Conservation division, the coordinator of the Makuleke contract park’s co-management } \\
\text { board, four of the NP’s social ecologists involved in the NP forums, community chairpersons for three of the NP forums }\end{array}$ \\
\hline Kgalagadi & $\begin{array}{l}\text { NP manager, head of the Kgalagadi's People and Conservation division, two Mier and one } ¥ \text { Khomani San representative } \\
\text { from the contract park's co-management board, one } ¥ \text { Khomani San represent ative from the NP forum }\end{array}$ \\
\hline
\end{tabular}

${ }^{a}$ Representatives from the Piikani Nation were not contacted for this study. 


\section{Assigning Ratings}

All interview and document data was separated for each NP using an Excel spreadsheet to organise the codes pertaining to a given indicator. Each piece of datum (e.g., an excerpt from an interview transcript, document, etc.) under any one code was assigned a score using a 4-point ordinal scale in which a ' 3 ' was 'very satisfactory' and a '0' was 'very dissatisfactory' (Table 4). The database also included notes on the rationale for the ratings assigned. For instance, for the indicator 'extent to which there is access for medicinal/food plants', Waterton Lakes was assigned a score of ' 1 ' (i.e., a 'dissatisfactory' score), because the local First Nations on the periphery had requested the right to collect plants in the NP, but the NP 'had been silent [as yet] on access for plants'. Had managers at Waterton Lakes dismissed the request outright, thereby eliminating all hope of access, a score of ' 0 ' would have been assigned. The Kruger was assigned a '2' or 'satisfactory' score because the Makuleke comanagers were allowed to collect some plants in parts of the NP, yet because harvesting had not in fact begun as the NP was still establishing its policy for medicinal plant use in the contract park a ' 3 ' was not warranted; i.e., the '2' reflects the effort on the NP's behalf, but still suggests room for improvement. Pacific Rim received a score of ' 3 ' because the NP's Aboriginal Liaison noted that the First Nations are able to "hunt or remove mushrooms or medicinal plants... they come to us and we let the wardens know," hence the "very satisfactory' arrangement.

NPs varied in the amount of information available for each indicator, from as low as one to as many as seven pieces of interview and/or archival data for each indicator. The scores for each indicator were thus averaged to determine an overall score for that indicator. The quality of our data analysis was cross-checked for logical consistency within and across indicators, and verified on site at two of the six case study NPs. The first author presented the final results to several co-managers at Gwaii Haanas and Kgalagadi and asked them to review the interpretation of the findings and comment on their accuracy.

Table 4

Rating scale for evaluating equity

\begin{tabular}{|ll|l|l|}
\hline Rating & \% of optimum & Colour & Description \\
\hline 3 & $76-100$ & Dark green & Very satisfa ctory \\
\hline 2 & $52-75$ & Light green & Satisfactory \\
1 & $26-51$ & Yellow & Dissatisfactory \\
\hline 0 & $0-25$ & Red & Very dissatisfactory \\
\hline
\end{tabular}

Note: A rating of ' 2 ' or ' 3 ' denotes a satisfactory level of equity (adapted from Arias \& Valery 1999)

\section{Calculating Overall National Park Equitability}

In order to calculate an overall 'equity' score for each $\mathrm{NP}$, we first calculated the individual criteria scores for each NP using the following formula:

$$
\text { Criterion equity }=\frac{\text { Sum of indicator scores for criterion }}{\begin{array}{c}
\text { Total possible score for criterion } \\
(\text { e.g., number of indic ators } \times 3)
\end{array}}
$$

A high quotient meant the NP had achieved a high score proportionate to the score that could have potentially been achieved, and hence was performing well on the indicators within that criterion. We then converted these proportions into percentages, and averaged the percentage scores for all three criteria for each NP to obtain the NP's overall equity score. Lastly, the relative contribution of the three criteria to each NP's overall equity score was assessed. For each NP, the scores for the three criteria were summed. The individual criterion scores were then divided by that sum to determine what proportion of the overall equity score could be attributed to each criterion.

\section{Sensitivity Analyses: Controlling for the Unintended Influences of Population Density and National Park 'Newness'}

Two sensitivity analyses were completed in order to control for any unintended influences that human population density and NP 'newness' might have on the results. First, with several of the case study NPs (e.g., the Kruger and Waterton Lakes) characterised by the presence of one or more communities and/or high land-use pressures located on their periphery, we controlled for density to ensure that the scores for NPs with very low to no pop ulation density on their borders (e.g., Kluane and Gwaii Haanas) were not 'inherently advantageous' due to fewer proximate social pressures. This helped eliminate evaluation outcomes that could in theory be a function of 'low density' and not intentional management actions per se. We approached this possibility by conducting a 'density test' wherein each indicator was re-assessed to ensure that NPs were not given 'extra' points for management actions they simply did not do or need to do given an absence of dense local populations. This was accomplished by isolating each indicator that reflected actions that were not an issue in a NP given that NP's low population density. In such cases, we attributed a ' 0 ' or 'very dissatisfactory' score so as to ensure no assignation of points for unintentional actions. For example, damage-causing animals (the term used by SANParks for NP wildlife such as elephants, lions, leopards that are said to have pushed through a weak portion of the NP's boundary fence and damaged local agricultural lands, gardens, etc., of those 
living on the NP periphery) were only considered a concern in a few NPs in this study (moreover, the concern is only likely when population density exists on the boundary of the NP). After attributing a ' 0 ' for these indicators, each NP's overall equity score was calculated as above and compared with the 'pre-density test' results.

A second sensitivity analysis was carried out to ensure that NP scores were not also influenced by their particular conditions of origin (e.g., newer NPs vs colonial era NPs). For instance, five of the six NPs and NP reserves in this study did not originate through negotiations with neighbouring indigenous groups. Gwaii Haanas is unique in having done so. Admittedly, Gwaii Haanas is a 'new era' and not a 'colonial' NP, the latter tending to be where land was appropriated without the consent of and against the wishes of traditional inhabitants. Gwaii Haanas took steps of this new and more equitable kind, and outcomes can be reasonably attributed to that effort towards change. In order to determine how effectively Gwaii Haanas would perform had it not received points for its negotiated establishment, we recalculated the NP's aggregate score by attributing a 'dissatisfactory' (Table 4) score to the five indicators related to land dispossession, relocation from the NP, negotiated NP establis hment and satisfaction with the co-manage ment agreement. The results of these recalculations are discussed below.

\section{RESULTS}

Table 5 presents the individual criterion equity scores, the overall equity score for each NP and compares the latter with the NP equity score after the density test. Scores are represented using percentage, numerical rating scores, as well as visually through the use of 'hatched colour' depictions. Five of the six NPs emerge as either 'satisfactory' or 'very satisfactory' with regard to overall equity scores; only one NP, Waterton Lakes, received a 'dissatisfactory' score overall. When overall NP equity scores were re-calculated using the adjusted indicator values derived from the density test, mean scores did change slightly, but did not affect the general pattern of findings or alter the ordering of the respective NPs. Nor did any one NP move from one scale level (e.g., 'dissatisfactory') to another (e.g., 'satisfactory'). Waterton Lake's overall equity rating did, however, decrease slightly after compensating for density. This suggests that population densities of NP-adjacent communities were generally not having an impact on NP equity scores.

Similarly, when recalculating Gwaii Haanas' ag gregate score to control for 'newness' as noted above, the NP's overall score for the 'resolution of land tenure and ownership' criterion decreased to 24 percent ('very dissatisfactory'). However, Gwaii Haanas NP still achieves an overall score of 75 percent (the upper end of 'satisfactory' and only 1 percent from being 'very satisfactory'), which would move it (overall) from the first to the second most equitable NP in this study after P acific Rim.

The relative proportion of the three criteria to each NP's overall equity score was also assessed. Figure 1 indicates the influence of each criterion on the NP's overall equity scores. Only Gwaii Haanas and Pacific Rim balanced the three equity criteria equally while the Kruger was close to doing so. There is, however, considerable variation across the NPs on these criteria. Gwaii Haanas and Pacific Rim received 'very satisfactory' scores overall for the 'resolution of land tenure and ownership' criterion (Table 5), whereas Kluane, the Kruger and Kgalagadi received 'dissatisfactory' scores.

The cross-indicator differences are also revealing to the extent that they shed light on key problematic indicators. For example, five NPs received 'very dissatisfactory' scores pertaining to their founding as most were not products of negotiations with neighbouring indigenous groups. Only Gwaii Haanas received a 'very satisfactory' score on this indicator. Similarly, the legacy effects of relocation from NP land is the basis for 'dissatisfactory' scores for Waterton Lakes, Kluane, the Kruger and Kgalagadi NPs; however, some NPs indicate partial or full recoveries from this state though compensation (Pacific Rim and Gwaii Haanas) and the settlement of land claims or the establish ment of the contract parks (the Kruger and Kgalagadi). An examination of the coded responses from interviews explains this finding further: Waterton Lakes received 'dissatisfactory' scores because the Kanai First Nation reported dissatisfaction with the settled land claim and because no co-management agreement between the NP and the Kainai and the Piikani First Nations exists. One respondent noted that "there is not a real willingness on the NP's part to involve the Kainai" and that "there is not enough meeting [of] the tribe's needs because the relationship between [the Kainai's land manager] and the NP is only project specific".

The 'maintenance of livelihood opportunities' criterion produced 'very satisfactory' scores for three NPs (Kluane, Gwaii Haanas and Pacific Rim), 'satisfact ory' for two others (the Kruger and Kgalagadi), whereas Waterton Lakes received a 'dissatisfactory' score overall (Table 5). The contribution of this criterion to the overall NP equity score for Wateron Lakes was much higher than was the case for the other two criteria (Figure 1). Findings on some of the indicators pertaining to access are of particular note in that Waterton Lakes and Kgalagadi received 'dissatisfactory' and 'very dissatisfactory' scores, respectively, because the neighbouring indigenous groups were required to pay regular NP access fees unless NP use was for a cultural (e.g., vision quest) purpose. This is distinct from the other case studies, where entrance fees were not required. In Waterton Lakes, one respondent noted that paying entrance fees to enter the NP left some Kainai feeling like they were being 'treated like tourists like anyone else'. Waterton Lakes also received a 'very 
Figure 1

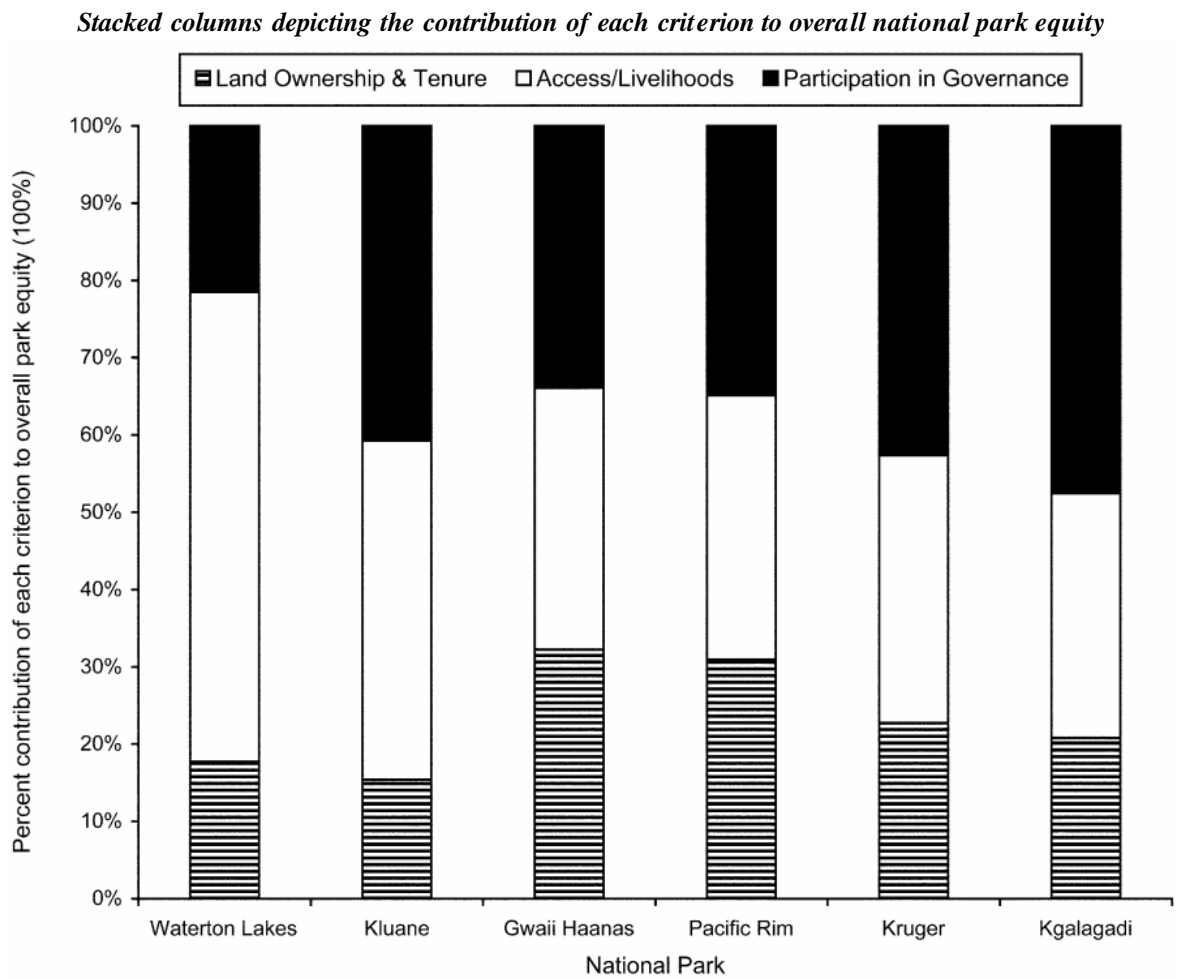

Table 5

Individual criterion equity scores, overall equity scores and equity score after density test

\begin{tabular}{|l|c|c|c|c|c|c|}
\hline Criteria & \multicolumn{5}{|c|}{ National Park } \\
\hline & Waterton Lakes & Kluane & Gwaii Haanas & Pacific Rim & Kruger & Kgalagadi \\
\hline Land tenure and ownership & 14 & 29 & 95 & 86 & 48 & 38 \\
\hline Livelihood opportunities & 48 & 83 & 100 & 95 & 73 & 58 \\
\hline Participation in NP governance & 17 & 77 & 100 & 97 & 90 & 87 \\
\hline Overall NP equity score & $26=1$ & $63=2$ & $98=3$ & $93=3$ & $70=2$ & $61=2$ \\
\hline NP equity score after density test & $22=1$ & $61=2$ & $95=3$ & $88=3$ & $70=2$ & $60=2$
\end{tabular}

Note: Individual criterion equity scores indicated by percentage; overall NP equity score and NP equity score after density test indicated by a percentage and a numerical rating score $(\%=$ score $)$.

dissatisfactory' score because the access rights for the Kainai and the Piikani First Nations were not negotiated but were decided upon by Parks Canada; whereas all other NPs received scores of 'very satisfactory' for this indicator.

Within the 'maintenance of livelihood opportunities' criterion, the Canadian NPs were considered to provide enough employment and received scores of 'satisfactory' and 'very satisfactory'. For example, Gwaii Haanas has a human resources plan that also addresses employment targets with regard to the Haida. One of the objectives stated in the plan is that there will be a minimum of 50 percent Haida at levels throughout the organisation (not just in junior staff positions, as is the case in some other NPs), and at the time the interviews were conducted (2006), the NP was at approximately 54 percent. Comparatively, the Kruger and Kgalagadi were considered to provide 'dissatisfactory' employment pportunities. This is somewhat surprising given that the People and Conservation division at the Kruger has focused on increasing small and medium sized business opportunities for neighbouring communities in the following ways: building small shops for local producers to sell their crafts at four NP gates and training community members to run the 
businesses; a contractor development programme where contractors are trained to run their own businesses; and a guideline that those winning tenders for construction in the NP must hire locally with SANParks maintaining and supplying a list of people who are employable as seamstresses, plumbers, thatchers and electricians. While Carruthers (2007) notes that employment and other legislation strongly favours previously disadvantaged black South Africans in the NPs, one Mier respondent interviewed from Kgalagadi commented: "you see contracts and development in the NP but somebody from outside the Mier gets the job". Likewise, one of the San representatives noted that "the trackers in the NP are not good...they are not San trackers, they are people who learn from the San but they are not good". This last comment is particularly telling as the San have a formidable reputation as expert hunters due to their outstanding tracking abilities (Magubane 1998).

While South African NPs did not perform well on employment, an added hardship emerged in the form of threats to livelihoods due to damage-causing animals, a point that was largely irrelevant to the Canadian NPs. In Kgalagadi, one respondent commented that "there is [sic] constantly comp laints about lions or wildlife coming out of the NP" and both the South African NPs were accused by neighbouring residents of not properly maintaining their fences and thus being unable to prevent damagecausing animals from escaping.

Several of the Canadian NPs had programmes to encourage the maintenance of cultural ties to the NP lands. For example, Kluane's 'Healing Broken Connections' programme includes a summer cultural camp which sees Parks Canada staff joining people from the ChampagneAishihik and the Kluane First Nations in activities including hiking, tanning hides and hunting a moose (Alces alces) for a traditional feast. Likewise, Gwaii Haanas has two programmes: a 'rediscovery camp' where Haida youth are able to learn about living on the land, survival and traditional Haida culture; and the 'Haida Watchmen Program' whereby elders act as ambassadors and educators at five sacred sites within the NP reserve in order to both protect the sites and to provide interpretation, from a Haida perspective, for visitors. There does not ppear to be an equivalent culture-centric camp in the South African NPs.

Five of the NPs received 'very satisfactory' scores overall on the 'participation in NP governance' criterion (Table 5). Only Waterton Lakes received a 'very dissatisfactory' score; one respondent from the Kainai believes "co-management arrangements are excellent and would like to see more on that" but that "there is not a real willingness on the NP's part to involve the Kainai". The comanagement boards at Gwaii Haanas and the Kruger were considered to have 'very satisfactory' and 'satisfactory' levels of authority over decision-making, respectively. In the Kruger, one of the members of the
Makuleke joint management board noted that " 75 percent of the people in the community were satisfied" with the contract park agreement. A good foundation has been prepared for formal co-management at Pacific Rim with the NP operating in a 'post-treaty environment' where there are various memoranda of understanding, access agreements and terms of reference agreements through which the NP works cooperatively with the neighbouring First Nations. 'Dissatisfactory' scores emerged for Kgalagadi and Kluane with one respondent from Kluane commenting that their mandate "is only making recommendations and guiding and steering...we aren't active in the management decisions".

All of the NPs were considered to be 'satisfactory' and 'very satisfactory' in reference to other opportunities for contributing to and influencing decision-making (such as NP forums). For example, a key purpose of the decadeold Quu'as West Coast Trail Society in Pacific Rim is 'more meaningful input into the management along the West Coast Trail'. Regarding the NP forums in South Africa, one respondent from Kgalagadi commented that "it is good to have that structure there so we can deal with the issues of the NP". In the Kruger, there was mixed feedback on the success of the NP forums. One respondent commented that the NP forum is "a good process that seems to be working" as they "have seen many results in terms of employment, in entrance into [the NP], in terms of fixing the fence". Yet, two other respondents provided the following comments: "I'm not sure the NP really wants the communities to have any decisionmaking power because maybe if they [the communities] become strong the NP will become fearful and resentful" and "the problem with the NP is that you can voice an opinion but nothing happens on the NP's side, there is no local decision-making power". In both the Kruger and Kgalagadi, attendance at the NP forum meetings could be improved by providing compensation for people to attend the meetings (in the form of money for petrol), food and/or cold drinks, financial compensation for the administration and paper for the atendees to take notes.

\section{DISCUSSION}

National governments in Canada and South Africa are charged with the difficult task of reconciling the goals of conservation of biological diversity with ongoing land restitution processes (Carruthers 2007). To be considered equitable from an indigenous perspective, PA managers must protect indigenous titles and access rights, while involving them in PA management and decision-making (including co-management or its functional equivalent where appropriate) on a fair and equitable basis (Colchester 2004; Blaustein 2007). This study utilised three central criteria of equity to systematically evaluate six NPs and NP reserves in Canada and South Africa. They are, 
again and as delineated above: resolution of land tenure, maintenance of livelihood opportunities and access rights to NP resources, and decision-making authority in NP governance. Each will be discussed in this section along with the anticipated and actual outcomes of the study.

Historically, the overall failure in five of the six case study NPs to negotiate the establishment of the NPs with neighbouring indigenous groups has been accompanied in the present by a failure of redress in the form of compensation for livelihoods (mostly land) lost and relocations then imposed. Such patterns of loss and relocation historically drove the generally poor scores on the 'resolution of land tenure and ownership' criterion in this study. Cernea and Schmidt-Soltau (2006) emphasise that NP managers have refused to acknowledge the disastrous socio-economic effects of displacement on people living already or as a result in chronic and in some cases extreme poverty (cf. Harper 2002). This is a particularly pertinent issue for the $\$$ Khomani San as the Kgalagadi contract park was to be partial compensation for their forced removal out of the NP. However, they continue to be one of the most oppressed groups of people in South Africa (Koch 1999 as cited in Reid et al. 2004), possibly due to little training and livelihood opportunities provided by the NP.

Much of current and proposed NP lands are contested spaces both historically and in reference to the contemporary period. In some cases, people have been considerably harmed by forced removal or a loss of key use and access rights. Evidence of the impacts of displacement on indigenous communities has included direct material loss to livelihoods or dwellings (Brockington \& Igoe 2006), a lack of local knowledge suitable to ease the shift in livelihoods from forest-based activities to agriculture (McElwee 2006), and no assistance during the transition period or provision of alternatives to resources previously available from forests (Rangarajan \& Shahabuddin 2006). In other cases, especially in post-colonial or settler nations such as Australia and Canada, NPs and PAs are de facto battle grounds and key currencies of redress to the extent that they are used to: 'assert the bargaining power of a previously marginalised political constituency seeking human rights and environmental justice' (Carruthers 2007: 299). ${ }^{7}$ In the Canadian case, more recent land-use plans and decisions regarding PAs often anticipate future treaty or rights and title negotiations. PAs can thus act, in the current polit ical context as a priori [to treaty] events wherein the negotiations themselves recognise the legitimacy of the First Nation stakeholders. In other cases, the emergence of new land-use plans including PAs may at the very least involve negotiations specific to the concerns and rights of First Nations whose traditional territory overlaps with a proposed PA (Clapp 2004).

Given the contested nature of a large number of PAs, as well as their current status in negotiations of redress in some nation states, we anticipated that the satlement of land claims would be the most important criterion in determining overall NP equity in this study. By this we mean that if a land claim had been settled, we anticipated the NP would perform very well on all other aspects, including access to resources and livelihood pportunities, employment and governance in decision-making. Interestingly, this expectation was not supported by the esults. Gwaii Haanas was the most equitable NP in the study, yet the Haida Nation were one of only two indigenous groups in the study that had not settled a land claim. While the Maa-nulth land claim encompass ing Pacific Rim and including several of the region's First Nations had not been formally settled at the time of research (the Final Agreement was accepted by the relevant First Nations in October 2007), this NP performed well on all other criteria and indicators and was considered equit able. Only Kluane performed the way we had anticipated; the Kluane and the Champagne-Aishihik First Nations deemed their land claim to be 'very satisfactory' and the NP also received 'satisfactory' scores on the 'maintenance of livelihood opportunities' and 'participation in NP go vernance' criteria. The previously mentioned 'Healing Broken Connections' programme in Kluane has helped to re-establish traditional links with the land and to enable the Champagne-Aishihik and the K luane First Nations to regain their knowledge of the land.

Comparatively and conversely, the Kainai and the Piikani First Nations (Waterton Lakes), the Makuleke (Kruger), and the Mier and the $\$$ Khomani San (Kgalagadi) had settled land claims, yet these NPs received very low scores for this criterion. This finding is important as it underscores the need for NP managers to provide livelihood and employment opportunities and involvement in NP governance processes, regardless of the state of any land claims in process or completed. NPs with settled land claims (however acceptable) must still account for and strive to be effective on the other two criteria. Contrary to what we had anticipated, the results from Gwaii Haanas demonstrate that the absence of a land claim can still result in a positive relationship between NP management and indigenous neighbours.

There are a number of factors that might explain this variability regarding the power of the 'land claims' crit eria to determine overall NP equity. One possibility is that the criterion is not subtle enough to capture the full history of negotiations between indigenous or local people and state governments. For instance, while neither Gwaii Haanas nor Pacific Rim had settled claims, negotiations concerning both NPs have been 'land claim like'. Pacific Rim has reshaped itself in response to some Maa-nulth concerns given the precedents of recent court decisions in British Columbia that have recognised the legitimacy of the First Nation land claims and which have in turn increased the likelihood that designations and reconsiderations of land-use (in particular, NPs and PAs) will involve measures of redress. ${ }^{8}$ 
A history of forced displacement from PAs and the loss of livelihood opportunities mean that careful attention must be given to reinstating the access rights of indigenous people to at least some of the resources within PAs encompassed by their traditional territories. For each of the case studies, access rights to the NPs were explicitly stated in some form of final land claim agreement, such as the Champagne and the Aishihik First Nations Final A greement (MSSC 1993), and the Kluane First Nation Final Agreement (MPWGSC 2003). Access is permitted to all NPs for cultural purposes (such as for vision quests), and arrangements for hunting, fishing, timber cutting and plant collection were allowed in all but Waterton Lakes and Kgalagadi. ${ }^{9}$ Employment, which might also be seen as a viable alternative (albeit only patial) for lost access or property, remains somewhat problematic in South Africa though less so in the Canadian Parks-no doubt at least partially a reflection of the disparate economic status of each country. Yet some promise is evident in this regard when considering the capacity building and training opportunities in all but Waterton Lakes and Kgalagadi. We anticipated that some NPs would work to offset lesser access or co-management regimes with better access to employment (as a kind of quid-pro-quo exchange). This anticipated outcome was, however, supported by the results from only two NPs (Waterton Lakes and Kgalagadi). For the remaining four NPs, each performed equally well on points of access, employment and co-management.

Finally, our purposive sample of NPs with varying levels of co-management demonstrates that effective and equitable participation in governance can be achieved. Indeed, we expected this feature to be so significant that we surmised early on that NPs with more intricate levels of co-management would be more equitable than NPs with lower levels of co-management. The results did in fact support this hypothesis in that Waterton Lakes, with the lowest governance score, had the lowest overall equity score, and the NPs with the highest governance scores were those with the better equity scores. Berkes (2004) posits that management institutions need to be empowered if they are to have the incentive to manage effectively. The AMB at Gwaii Haanas appears to excel in this regard as it has full decision-making authority over the NP, makes decisions based on consensus and benefits from the use of issue forms. Issue forms are es sentially a shortcut key to help the AMB make decisions about actions to take in the NP reserve whereby managers and scientists use the forms to present the scientific background and their professional recommendations to the AMB, enabling the AMB co-managers to make informed decisions.

The effectiveness of Gwaii Haanas should be understood in reference to several key factors outstanding in this NP and not present in the other case studies. Gwaii Haanas was established in 1993 and is thus a 'new era' and not a 'colonial' NP. It also came into being after extensive negotiations between the federal and provincial governments and the Haida Nation, and was indeed init iated by the Haida Nation. The Haida were never displaced from the NP lands, having already lived outside of the NP boundaries when it was established. Their rights within the NP include, among other things, travel within the archipelago, gathering of traditional Haida foods, cutting of selected trees for ceremonial or artistic purposes, hunting, trapping, fishing, and use of shelters and facilities essential to the pursuit of these activities (AMB 2002). Gwaii Haanas had (at the time of fieldwork in 2006) also exceeded its employment targets of having 50 percent of the positions across different sections of the organisation staffed by the Haida. Finally, there appears to be a certain synergy established between members of the AMB. While the early years on the AMB were fraught with the difficulties of establishing an effective group dynamic whilst managing a new NP, several of the AMB members remarked that "the whole framework is great and it is a good model that we can keep on using, with slight changes...that's all there is to it" and the AMB "just works". The continuity of having virtually the same members on the AMB throughout the years has likely contributed to their productive working relationship.

At the outset of the study, we also anticipated finding that some NPs were co-managed in name only. By this we mean that while a co-management board might have existed, delegated decision-making to the board only occurred on a partial basis. This expectation was supported by the results for three of the case study NPs in that Kluane, the Kruger and Kgalagadi were all restricted in the kinds of decisions they could make. The Kgalagadi co-management board was generally restricted to making decisions about infrastructure (e.g., roads, tourist lodges, new NP gate and gate fees) in the NP, while the Kruger co-management board made similar decisions while also addressing issues such as who was able to hunt and collect resources, maintenance of the western boundary fence, how concessions for game drives are made and which roads are used for game drives. Only the AMB at Gwaii Haanas made decisions about all aspects of the NP, including those regarding scientific evidence and specific conservation management actions. This finding lends support for the argument that indigenous co-managers, working closely with their government counterparts and supported in their decision-making by relevant scientific advice, are an effective means by which to manage NPs located within their traditional territories.

That said, 'measurements' of co-management of this kind can only be taken as a loose proxy of practice and intent with regard to both the involvement of indigenous stakeholders in the management of NPs and any improvements in the use of traditional knowledge that are often a part of such local-vs-expert engagements in management. Many closer looks at co-management regimes emphasise 
the finding that the knowledge inputs or 'data' gathered by local people is often dismissed as ill suited to the parameters of scientific research (Nadasdy 1999), and that claims about the justness and efficacy as well as potential benefits of co-management should not be accepted at face value (Nadasdy 2005). The point for understanding the role of co-management may not be a question of 'if' or 'how much' co-management is achieved, as we have tried to do here, but 'what in fact' people are empowered to do (Henkel \& Stirrat 2001). In future studies, it might be just as important to ask whether, for instance, indigenous or local people are empowered to realise land-use in their own vision of the future and/or based on their own empirical knowledge, or are they simply empowered to asert the systems of rule, land management and social relations already politically entrenched within the NP or nation state more broadly and likely inequitable to varying degrees?

In retrospect, these and additional qualifications as to points of weaknesses and scepticism should be noted. While in the above interpretation of some of our findings, we have pointed to possible problems with how the crit eria pertaining to land claims and co-management were measured, we should also note some potential problems with methods more broadly. First, we did not complete as many interviews as we would have preferred and in this sense a larger or different sample of participants might well alter our findings. For instance, the first author, who conducted all of the interviews, was only able to interview one of the four $\$$ Khomani San representatives from the co-management board (while also interviewing two Mier representatives and one of the $\ddagger$ Khomani San NP forum representatives, Table 3). This was due to an inability to contact the other three representatives despite repeated attempts [it is common for phone lines to be inoperative (often due to the theft of copper cables) in that part of South Africa]; and only three of a possible seven NP forum chairmen from the Kruger were interviewed. Second, the rating scale amended for this research (Table 5) seems logical and is reasonably straightforward to use (Salafsky \& Wollenberg 2000); yet our attribution of scores to individual indicators (though careful and, we hope, logically consistent), was also by definition internally subjective in cases where the scores were not assigned by the participants themselves. Interview espondents did often indicate their direct level of satisfaction (e.g., 75 percent satisfied) or gave a clear answer to which a score could easily be assigned, but in other instances we had to attribute a score based upon our assessment of their response.

Furthermore, our findings on some points might well have differed were we able to rely less heavily on documents per se (secondary data), and more fully on richer field data or respondents' narrative experiences of sp ecific local practices and histories. For instance, the indicator dealing with the extent to which local indigenous people were dispossessed of land was based on archival and oral history, and not on respondent's 'satisfaction' with or judgements of that process. We also assumed that each criterion was equally important to the equity evaluation and thus each was attributed an equal weight therein. Future research into the relative importance of our (or other, new) criteria to equity in NPs is appropriate, esp ecially given the importance implied herein to co-management efforts and their relation to equity. Finally, the case study NPs all varied in size, primary ecosystem type, comanagement strategy, and type and degree of threats. While we believe this adds depth and breadth to the results found and conclusions made, it is possible that these (very few) case study NPs were all anomalous and do not accurately portray how equitable NPs are.

\section{CONCLUSION}

As employees of parastatal agencies, NP managers are expected to be accountable to global agreements, such as the Convention on Biological Diversity, to which their governments are signatories, as well as to the equity concerns central to this paper. These include the protection of property and human rights and the relationship between rights holders (indigenous people) and duty bearers (NP managers) (Blaustein 2007). Our results indicate that more can be done in terms of mitigating the social and economic impacts of NPs, and to improve access to NP resources and livelihood opportunities for local indigenous people. However, this study showcases a promising trend toward equity in the management of NPs, although greater implementation of co-management practices is warranted most notably in Waterton Lakes and Kgalagadi. Waterton Lakes cannot, for example, be considered an equitable NP at this time (given the lack of indigenous participation in NP governance and access to NP resources, among other things), yet the potential evident therein should be noted. There is, for instance, a relationship based on mutual respect between the NP's superintendent and the tribal land manager for the Kainai Nation as these two individuals communicate about management activities bordering on the Kainai land and speak of their admiration for each other. Similarly, most NPs involved in this study have all worked hard to overcome a common legacy of land dispossession, resolve land tenure and access rights into the NPs, and address issues of participation in governance; there is no reason to assume that Waterton Lakes cannot do the same even if a formal comanagement board is not the selected solution.

NPs will be challenged to conserve the biological diversity within their borders if they continue to operate under difficult social and political conditions and are faced with unnecessarily poor relations with local indigenous communities. The need for genuine involvement of indigenous and other local people in the governance of NPs is evident when considering that many NPs face a 
diversity of threats, including inadequate management of resources, human encroachment, the collection of nontimber forest products, logging (mainly illegal), illegal harvesting and adjacent land development (Hockings 2003; Lacerda 2004). Even in heavily fortified NPs such as the Kruger, the illegal harvesting of wildlife occurs on a regular basis. In all but the most strictly community controlled PAs, indigenous people have previously had very little equity in decision-making, and the relationship between NP agencies and local communities has generally been paternalistic and unidirectional (Stankey 1989; Ferguson 1994; Harper 2002; Loo 2006). A shift in power over governance from bureaucratic authority to these people themselves may be difficult as governments will likely have trouble accepting that other viable management methods exist. In order to encourage and enable the development of more equitable NPs, best practices need to be identified. For instance, best practices for resettlement should require the prior, free and informed consent of the affected people (Schmidt-Soltau \& Brockington 2007). Likewise, a systematic approach to evaluating the equity of NPs would better highlight the social and cultural context of NPs.

Finally, while the results of this study also demonstrate that greater equity in NPs is possible, success for people does not necessarily mean success for nature (Brockington et al. 2006). Differences regarding priorities for PA management often reflects professional and disciplinary lines, a fragmentation and specialisation of knowledge, and ecologists and conservation biologists emphasising something different from social scientists and peoples' rights advocates (A dams \& Hutton 2007; Blaustein 2007; King et al. 2007). It is necessary to reconcile any differences between the social and ecological realms in order to ensure NPs are simultaneously ecologically effective and socio-culturally equitable.

\section{Acknowledgements}

We wish to acknowledge Dr John L. Innes, University of British Columbia Forestry, Dr Jane Carruthers and two anonymous reviewers from Conservation and Society for their constructive comments on an earlier version of this manuscript. This research would not have been possible without the participation of representatives from the $\$$ Khomani San, the Makuleke and the Mier communities in South Africa, and the Champagne-Aishihik, the Kluane, the Haida, the Kainai, the Huu-ay-aht, the Ucluelet, the Toquaht and the Tla-o-qui-aht First Nations in Canada. Funding for this research was generously provided by a Canadian Window on International Development Award (International Development Research Centre, Ottawa, Canada), the Transboundary Protected Areas Research Initiative (Wits University, Johannesburg, South Africa), the UBC Hampton Res earch Endowment Fund and an Asia Pacific Research University grant.

\section{Notes}

1. NPs were selected on the basis of having a management plan and monitoring data as well as being restricted to those with the presence of a $\Theta$-management board or involvement of local indigenous neighbours.

2. We use the ILO (1989) definition when referring to indigenous people: 'peoples in independent countries who are regarded as indigenous on account of their descent from populations which inhabited the country, or a geographical region to which the country belongs, at the time of conquest or colonisation....and who, irrespective of their legal status, retain some or all of their own social, economic, cultural and political institutions'.

3. We recognise that 'race' is (and should be) a contested term in the social sciences as efforts to distinguish biophysical features of racial groups have failed both genetically and phenotypically (Brace 2005). The construct 'race' expressed as 'visible minorities' is nonetheless the defining feature of formal apartheid systems and their post-apartheid derivatives.

4. During the pursuit of their land claim, the name $\ddagger$ Khomani San was the name chosen by a group of 'coloured people' — and within that group the San (bushman) in particular- "which were trying to coalesce around being accorded some kind of 'first nation' status and thereby establish a national presence with a discrete ethnic identity within a broader African population in which they felt marginalised" (Carruthers 2007: 302).

5. The Haida Gwaii is the Haida name given to the archipelago, which has also commonly been referred to by its colonial name, the Queen Charlotte Islands. Gwaii Haanas is the name of the NP eserve and the Haida heritage site.

6. Positive feedback was received during these meetings. One comment in particular was made by a Haida/Gwaii Haanas co-manager who said "...these results make sense to me ... I understand these results and what you did".

7. Following Carruthers (2007), in South Africa, the term 'minority' reflects the imbalance of power but is otherwise a misnomer, as the constituency for the most part is in fact the majority: the Africans.

8. In the aftermath of the Delgamuukw case, which was the first of several cases to determine that most British Columbia First Nations had not ceded lands or settled treaties with the Crown, federal and provincial governments are required to consult on anything that might affect lands affiliated with pending indigenous rights and title claims. More recently, a British Columbia Supreme Court judge found that the provincial government did not have jurisdiction over 200,000 ha of land claimed by the Tsilhqot'in First Nation (Xeni Gent'in) as tests for evidence of title were met in almost half the area claimed.

9. While fishing and timber cutting did not appear to be important issues for the Mier and the $¥$ Khomani San in Kgalagadi, hurting and the collection of plants were more pertinent issues.

\section{REFERENCES}

Adams, W.A. and J. Hutton. 2007. People, parks and poverty: Political ecology and biodiversity conservation. Conservation and Society 5(2): 147-183.

Adams, W.M., R. Aveling, D. Brockington, B. Dickson, J. Elliott, J. Mutton, D. Roe, B. Vira and W. Wolmer. 2004. Biodiversity conservation and the eradication of poverty. Science 306: 11461149.

Agrawal, A. 2003. Sustainable governance of common pool resources. Annual Review of Anthropology 32: 243-262.

AMB (Archipelago Management Board). 2002. Gwaii Haanas National Park Reserve and Haida Heritage Site: Draft strategic management plan for the terrestrial area. Parks Canada Agency, Canada. 
Arias, M.C. and A.I. Valery. 1999. Evaluation of protected areas management effectiveness: Analysis of procedures and outline for a manual. WWF Centroamerica, Turialba, Costa Rica.

Babbie, E. and L. Benaquisto. 2002. Fundamentals of social research: First Canadian edition. Scarborough: Thomson/Nelson.

Balint, P.J. 2006. Improving community-based conservation near protected areas: The importance of development variables. Environmental Management 38: 137-148.

Baral, N. and J.T. Heinen. 2007. Decentralization and people's partidpation in conservation: A comparative study from the Western $\mathrm{T}$ erai of Nepal. International Journal of Sustainable Development and World Ecology 14: 520-531.

Berg, L., T. Fenge and P. Dearden. 1993. The role of aboriginal peoples in national park designation, planning and management in Canada. In: Parks in Canada: Planning and management (eds. Dearden, P. and R. Rollins). Pp. 225-255. Toronto: Oxford University Press.

Berkes, F. 1994. Co-management: Bridging the two solitudes. Northern Perspectives 22: 18-20.

Berkes, F. 2004. Rethinking community-based conservation. Conservation Biology 18: 621-630.

Blaustein, R.J. 2007. Protected areas and equity concerns. BioScience 57: 216-221.

Bosch, D. 2003. Land conflict management in South Africa: Lessons learned from a land rights approach. Land Reform, Land Settlement and Cooperatives 2: 96-111.

Bosch D. and E. Hirschfeld. 2002. The!Ae!Hai Heritage Park bundleincluding the agreement whereby the land claims of the $\$$ Khomani San community and the Mier community are finalised and associated documents. Commission on the Restitution of Land Rights, Pretoria, South Africa.

Boyatzis, R.E. 1998. Transforming qualitative information: Thematic analysis and code development. Thousand Oaks: Sage Publications.

Brace, C.L. 2005. 'Race' is a four-letter word: The genesis of the concept. New York: Oxford University Press.

Brechin, S.R., P.C. West, D. Harmon and K. Kutay. 2001. Resident peoples and protected areas: A framework for inquiry. In: Resident peoples and national parks: Social dilemmas and strategies in international conservation (eds. West, P.C. and S.R. Brechin). Pp. 528. Tucson: The University of Arizona Press.

Brockington, D. 2002. Fortress conservation, the preservation of Mkomazi Game Reserve, Tanzania. London: James Currey.

Brockington, D. and J. Igoe. 2006. Eviction for conservation: A global overview. Conservation and Society 4(3): 424-470.

Brockington, D., J. Igoe and K. Schmidt-Soltau. 2006. Conservation, human rights and poverty reduction. Conservation Biology 20: 250-252.

Brosius, J.P. 2004. Indigenous peoples and protected areas at the World Parks Congress. Conservation Biology 18: 609-612.

Bruner, A.G., R.E. Gullison, R.E. Rice and G.A. da Fonseca. 2001. Effectiveness of parks in protecting tropical biodiversity. Science 291: $125-128$.

Burdge, R.J. 1994. The social impact assessment model and the planning process. In: A conceptual approach to social impact assessment: Collection of writings by Rabel J. Burdge and colleagues (ed. Burdge, R.J.). Pp. 41-49. Middleton: Social Ecology Press.

Burdge, R.J. 2004. The concepts, process and methods of social impact assessment: Rabel J. Burdge and colleagues. Middleton: Social Ecology Press.

Buscher, B. and W. Whande. 2007. Whims of the winds of time? Emerging trends in biodiversity conservation and protected area management. Conservation and Society5(1): 22-43.

Carruthers, J. 2006. Tracking in game trails: Looking afresh at the politics of environmental history in South Africa. Environmental History 11: 804-829.
Carruthers, J. 2007. 'South Africa: A world in one country': Land restitution in national parks and protected areas. Conservation and Society 5(3): 292-306.

Carruthers, J. 2008. Conservation and wildlife management in South African national parks 1930s-1960s. Journal of the History of Bio$\log y$ 41: 203-236.

Cernea, M.M. and K. Schmidt-Soltau. 2006. Poverty risks and national parks: Policy issues in conservation and resettlement. World Development 34: 1808-1830.

Chambers, R. and G.R. Conway. 1991. Sustainable rural livelihoods: Practical concepts for the $21^{\text {st }}$ century. Sussex: Institute of Development Studies.

Clapp, A. 2004. Wilderness ethics and political ecology: Remapping the Great Bear Rainforest Political Geography 23: 839-862.

Colchester, M. 2004. Conservation policy and indigen ous peoples. $\mathrm{Cul}$ tural Survival Quarterly 28(1). URL: http://209.200.101.189/ publications/csq/csq-article.cfm?id=1738 (last accessed November 2007).

DJC (Department of Justice Canada). 2000. Canada National Parks Act. URL: http://laws.justice.gc.ca/en/ShowDoc/cs/N14.01///en?page= $1 \&$ isprinting $=$ true (last accessed August 2008).

DLASA (Department of Land Affairs of South Africa). 1994. Restitur tion of Land Rights Act. URL: http://land.pwv.gov.za/restitution/ RSTEAJM.html (last accessed August 2008).

Ferguson, J. 1994. The anti-politics machine: Development, depoliticalization and bureaucratic power in Lesotho. Minneapolis: University of Minnesota Press.

Ghate, R. 2003. Global gains at local costs: Imposing protected areas: Evidence from central India. International Journal of Sustainable Development and World Ecology 10: 377-389.

Gibson, C.C. and S.A. Marks. 1995. Transforming rural hunters into conservationists: An assessment of community-based wildlife managements programs in Africa. World Development 23: 941957.

Grossman, D. and P. Holden. 2002. Contract parks in South Africa. URL: http://www.conservationdevelopment.net/Projekte/Nachhaltigkeit/CD1/Suedafrika/Literatur/PDF/Grossmann.pdf (last accessed August 2008).

Harper, J. 2002. Endangered species: Health, illness and death among Madagascar's people of the forest. Durham: Carolina Academic Press.

Henkel, H. and R. Stirrat. 2001. Participation as spiritual dut y: Empowerment as secular subjection. In: Participation: The new tyranny (eds. Cooke, B. and U. Kothari). Pp. 168-184. London: Zed Books.

Hockings, M. 2003. Systems for assessing the effectiveness of management in protected areas. Bioscience 53: 823-832.

Hughes, C.A. 2005. Nothing changes in the Kalahari: Kgalagadi Transfrontier Park, the Ae!Hai Kal ahari Heritage Park agreement and the effects of difference, discourse and the past. Unpublished Masters Thesis, Department of Social Anthropology, University of Cape Town, South Africa.

ILO (International Labour Organization). 1989. Indigenous and Tribal Peoples Convention 169. URL: http://www.ilo.org/ilolex/cgi-lex/ convde.pl?C169 (last accessed November 2007).

IUCN (The World Conservation Union). 1994. Guidelines for protected area management categories. URL: http://www.unepwcmc.org/ protected_areas/categories/eng/ii.pdf (last accessed January 2008).

King, N., H. Biggs and R. Loon. 2007. Seeking common ground: How natural and social scientists might jointly create an overlapping worldview for sustainable livelihoods: A South African perspective. Conservation and Society5(1): 88-114.

Koch, E. 1999.Tracker training and the cybertracker: A rapid evalua tion. Unpublished report, South Africa National Parks, Pretoria, South Africa.

Lacerda, L. 2004. Are protected areas working? An analysis of forest protected areas by WWF. Gland: WWF. 
Loo, T. 2006. States of nature: Conserving Canada's wildlife in the twentieth century. Vancouver: UBC Press.

Magome, H. and J. Murambedzi. 2003. Sharing South African national parks: Community land and conservation in a democratic South Africa. In: Decolonizing nature: Strategies for conservation in a post-colonial era (eds. Adams, W.A. and M. Mulligan). Pp. 108134. London: Earthscan Publications Ltd.

Magubane, P. 1998. Vanishing cultures of South Africa: Changing customs in a changing world. New York: Rizzoli.

McElwee, P.D. 2006. Displacement and relocation redux: Stories from Southeast Asia. Conservation and Society 4(3): 396-403.

McKean, M.A. 2000. Common property: What is it, what is it good for and what makes it work? In: People and forests: Communities, institutions and governance (eds. Gibson, C.C., M.A. McKean and E. Ostrom). Pp. 27-55. Cambridge: MIT Press.

MPWGSC (Ministry of Public Works and Government Services Canada). 2003. Kluane First Nation final agreement among the Government of Canada and Kluane First Nation and the Government of the Yukon. URL: http://www.ainc-inac.gc.ca/pr/agr/klu/fia_e.html (last accessed October 2007).

MSSC (Ministry of Supply and Services Canada). 1993. Champagne and Aishihik First Nations final agreement between the Government of Canada, the Champagne and Aishihik First Nations and the Government of the Yukon. URL: http://www.aincinac.gc.ca/ pr/ agr/ykn/chama_e.pdf (last xcessed October 2007).

Morgan, N., E. Kellogg, A. Thompson, I. Gill and F.G. Chambers. 1997. More than the sum of our parks: People, places and a protected areas system for British Columbia. URL: http://www. ecotrust.org/publications/MoreThanTheSumofOurParks_Text.pdf (last accessed August 2008).

Morrison, J. 1997. Protected areas, conservations and aboriginal interests in Canada. In: Social change and conservation: Environmental politics and impacts of national parks and protected areas (eds. Ghimire, K.B. and M.P. Pimbert). Pp. 270-296. London: Earthscan Publications Ltd.

Nadasdy, P.1999. The politics of TEK: Power and the 'integration' of knowledge. Arctic Anthropology 36: 1-18.

Nadasdy, P. 2005. The antipolitics of TEK: The instit utionalization of co-management discourse and practice. Anthropologica 47: 215232.

Neumann, R.P. 1998. Imposing wilderness: Struggles over livelihood and nature preservation in Africa. Berkeley: University of California Press.

Oltremari, J.V. and R.G. Jackson. 2006. Conflicts, perceptions and expectations of indigenous communities associated with nat ural areas in Chile. Natural Areas Journal 26: 215-220.

PC (Parks Canada). 2003. Pacific Rim National Park Reserve of Canada. URL: http://www.pc.gc. ca/pn-np/bc/pacificrim/plan/index_e.app (last accessed January 2008).

PC (Parks Canada). 2004. Kluane National Park and Reserve of Canada: Management plan. URL: http://www.pc.gc.ca/pn-np/yt/kluane/ plan/plan_forward_E.asp (last accessed August 2008).
Pfeffer, M.J., J.W. Schelhas and L.A. Day. 2001. Forest conservation, value conflict and interest formation in a Honduran National Park Rural Sociology 66: 382-402.

Rangarajan, M. and G. Shahabuddin. 2006. Displacement and reloca tion from protected areas: Towards a biological and historical sy nthesis. Conservation and Society 4(3): 359-378.

Reid, H., D. Fig, H. Magome and N. Leader-Williams. 2004. Co -mana gement of contractual national parks in South Africa: Les sons from Australia. Conservation and Society 2(2): 377-409.

Salafsky, N. and E. Wollenberg. 2000. Linking livelihoods and conservation: A conceptual framework and scale for assessing the integration of human needs and biodiversity. World Development 28: $1421-1438$

SANParks (South African National Parks). 2000. Visions of change. Development Communications corporation and SANParks, Pret oria, South Africa.

SANParks (South African National Parks). 2007. Park forums. URL: http://www.sanparks.org/people/community/default.php (last accessed November 2007).

Schmidt-Soltau, K. and D. Brockington. 2007. Protected areas and tesettlement: What scope for voluntary relocation? World Development 35: 2182-2202.

Stankey, G.H. 1989. Linking parks to people: The key to effective management. Society and Natural Resources 2: 245-250.

Terborgh, J. 2004. Reflections of a scientist on the World Parks Congress. Conservation Biology 18: 619-620.

Timko, J. and T. Satterfield. 2008. Criteria and indicators for evaluating socio-cultural and ecological effectiveness in national parks and protected areas. Natural Areas Journal 28: 307-319.

Usher, P.J. 2003. Environment, race and nation reconsidered: Reflections on aboriginal land claims in Canada. The Canadian Geographer 47: 365-382.

Vanclay, F. and D.A. Bronstein. 1995. Environmental and social impact assessment. Chichester: Wiley.

Weitzner, V. and M. Manseau. 2001. Taking the pulse of collaborative management in Canada's national parks and national park reserves: Voices from the field. In: Crossing boundaries in Parks Management. Proceedings of the 11th Conference on Research and Resource Management in Parks and on Public Lands (ed. Harmon, D). Pp. 253-259. Hancock: The George Wright Society.

Wilshusen, P.R., S.R. Brechin, C.L. Fortwangler and P.C. West. 2002. Reinventing a square wheel: Critique of a resurgent 'protection paradigm' in international biodiversity conservation. Society and Natural Resources 15: 17-40.

Yin, R.K. 2003. Case study research: Design and methods-Third edition. Thousand Oaks: Sage Publications.

Zerner, C. 2003. Culture and the question of rights: Forests, coasts and seas in Southeast Asia. Durham: Duke University Press.

Supervising editor: Jane Carruthers

Received 5 March 2008 Revised 9 September 2008. Accepted 26 September 2008. 